O. Sheremet ${ }^{1}$, Dr. Sc. (Tech.), Assoc. Prof., orcid.org/0000-0003-1298-3617, O. Sadovoi ${ }^{2}$, Dr. Sc. (Tech.), Prof., orcid.org/0000-0001-9739-3661, Yu. Sokhina ${ }^{2}$, Cand. Sc. (Tech.), Assoc. Prof., orcid.org/0000-0002-4329-5182
1 - Donbas State Engineering Academy, Kramatorsk, Ukraine, e-mail: sheremet-oleksii@ukr.net

2 - Dniprovsk State Technical University, Kamianske, Ukraine, e-mail: sadovoyav@ukr.net

\title{
COMBINED CONTROL SYSTEM ON THE BASIS OF TWO DISCRETE TIME EQUALIZERS
}

Purpose. Development of a method for constructing the structure of the combined management with compensation of parametric and coordinate perturbations on the basis of two discrete time equalizers and experimental evaluation of the effectiveness of additional compensating equalizer.

Methodology. The theory of transition functions of finite duration is used to set the desired dynamic properties of automatic control systems in discrete time intervals. The modified structural schemes symmetry principle provides the formation of desired dynamic characteristics of closed-loop system with limited gain factor.

Findings. A method of designing a combined control structure with compensation of parametric and coordinate perturbations based on two discrete time equalizers is developed and experimentally tested. The method is one of the components of the methodology of the synthesis of automatic control systems, and provides the setting of the desired dynamic properties for the output coordinate in the graphical form or in the form of points set of the desired transient function.

Originality. The technique of designing the structure of the combined control system based on two discrete time equalizers (basic and compensating) was developed for the first time. The technique differs from the known (with only one discrete time equalizer) by the introduction of a parallel correction branch with a discrete time equalizer, configured to fully compensate for the dynamic properties of the control object. This makes it possible to reduce the sensitivity of the system to coordinate and parametric perturbations.

Practical value. The research results can be used for designing control algorithms for technical objects with their subsequent implementation program in the microcontroller or microprocessor control system.

Keywords: discrete time equalizer, synthesis, quantized transition function, transition function of finite duration, modified principle of symmetry

Introduction. In the implementation of automated electromechanical systems synthesis in most cases, methods are applied that cannot fully use the capabilities of modern computer technology and are based on the concept of a standard characteristic polynomial. The designer should choose the desired characteristic polynomial from a previously known list, based on some technical recommendations, nomograms, and instructions.

Wide proliferation and application into industrial production of computer and microcontroller technology and minimization of human factor influence are among the most significant trends in the development of modern production processes. Against this background, there is a relevant program assignment of the desired dynamic properties of a technical object, in which all computational work is carried out using modern computer technology without utilization of standard characteristic polynomials.

Based on the performed critical analysis of the methods of automated electromechanical systems synthesis, the necessity of developing a system of methods which would use quantized desired transition functions as requirements to the static and dynamic properties of the system was substantiated.

A mathematical apparatus is developed that allows the use of quantized desired transition function as a basis for automatic control systems synthesis without using of traditional approaches: the standard characteristic polynomials or Bode plots.

The discrete regulator, which provides the ability to tune up desired transition functions of finite duration on quantized, is called a discrete time equalizer.

Literature review. The studies [1] give the basic fundamental principles that allow synthesis of automatic control systems without using the standard characteristic polynomials [2]. These approaches allow synthesis of regulators based solely on the technical features of real objects and technological standards of their operation.

(C) Sheremet O., Sadovoi O., Sokhina Yu., 2020
When implementing the synthesis of automatic control systems with discrete time equalizers, the levels of the desired transient function are given at the moments of quantization [3]. Thus, the desired transition function is divided into a number of parts or ranges. It is possible to draw an analogy with the operation of such a device as an equalizer, which sets the local level of amplification on the local frequency bands [4]. However, a discrete time equalizer, unlike a traditional equalizer does not work in the frequency range, and in the time.

In the simplest case, the automatic control system synthesized by the method of the discrete time equalizer contains the following elements: a program for setting an input signal and coefficients of the discrete time equalizer; the discrete time equalizer; a digital-to-analog converter or zero-order holder $(\mathrm{ZOH})$ [5]; an inverse reference model of a controlled object; a controlled object receiving an input signal and having some perturbations; feedback sensor for output coordinate.

In [3] it was established that the application of one discrete time equalizer in an automatic control system allows implementation of the control principle over deviations, while ensuring the achievement of desired quantized transition functions. The system synthesized this way is astatic, but it has no opportunity to influence the proportional component.

It is known that the increase in the transmission coefficient is the most universal and effective method for increasing the dynamic accuracy and reducing the sensitivity of automatic control systems to parametric and coordinate disturbances.

Automatic control systems with one discrete time equalizer installed in the main transmission channel do not have the ability to influence on the proportional component and, consequently, cannot increase the transmission coefficient of the control system.

Purpose. Let us set up the task of developing a technique for constructing a structure of a combined control system with two discrete time equalizers (main and compensating), which provides compensation for parametric and coordinate distur- 


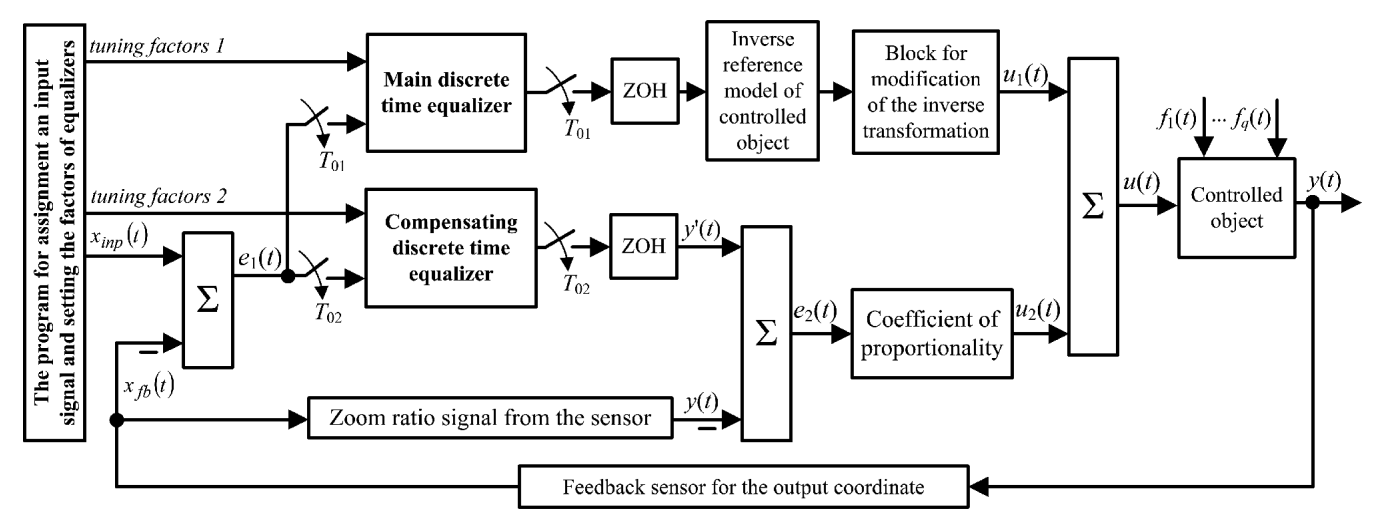

Fig. 1. Functional scheme of combined automatic control system on the basis of two discrete time equalizers

bances. In this case, the compensating discrete time equalizer, installed in the parallel branch, must be tuned to the full (ideal) compensation of the control object dynamic properties.

Methods. The research is based on the methods of analysis and synthesis of discrete systems of automatic control. Methods for solving inverse dynamics problems are used to determine inverse models of control objects in automated electromechanical systems.

Results. In order to influence the proportional component of the system, combined control can be applied, in which one of the discrete time equalizers works in a closed-loop and implements the control principle over deviations (the main control channel), and the other acts as a reference model that forms an additional control signal in open loop. In this case, the signal at the output of such reference model is scaled with some coefficient of proportionality.

The discrete time equalizer synthesized with full compensation of the dynamic properties of the controlled object can be used as a reference model that takes an error between the reference and the feedback signal as an input signal (Fig. 1). Designation of signals in Fig. 1: $e_{1}(t)$ - error between the input signal and feedback signal; $y^{\prime}(t)$ - output coordinate of the reference model; $e_{2}(t)$ - error between the output coordinate of the reference model and the output coordinate of the automatic control system; $u_{1}(t)$ - control signal formed in the main channel; $u_{2}(t)$ - control signal that is formed by reference model; $u(t)$ - control signal fed to the input object.

The quantization period of the main discrete time equalizer $T_{01}$ may vary from the quantization period of the compensating discrete time equalizer $T_{02}$. For practical reasons it is advisable to choose $T_{02}<T_{01}$. Since the output signal from the main discrete time equalizer goes to the block of modification of a reverse transformation, which is the integrating element, its step nature is replaced by piecewise monotonic character (straight lines).

The signal from the output of the compensating discrete time equalizer is not smoothed and retains its stepped character. If quantization periods of equalizers are commensurable with the time constant of control object, it can be chosen $T_{02}=$ $=T_{01}$. When the quantization time $T_{01}$ is several times larger than the largest time constant of controlled object, the choice $T_{02}=T_{01}$ can cause some local disturbance of the output coordinate, which form additional transients on the steps of the signal given by compensating discrete time equalizer (Fig. 2).

Since both the main and the compensating equalizers are tuned to the same desired transition function, the resampling of quantized form of transition function is necessary for minimizing $T_{02}$. In order to simplify the technical implementation of this approach, it is advisable to choose

$$
T_{02}=T_{01} / m, \quad m=2,3,4,5, \ldots .
$$

The structural scheme of combined automatic control system on the basis of two discrete time equalizers is shown in Fig. 3. Designation in Fig. 3: $W_{e q 1}(z)-$ transfer function of the main discrete time equalizer; $W_{e q 2}(z)$-transfer function of the compensating discrete time equalizer; $W_{i n v}(p)$ - transfer function of the controlled object inverse model; $W_{o b j}(p)-$ transfer function of the controlled object; $W_{\bmod }(p)$ - transfer function of the block for modification of the inverse transformation; $k_{a v}$ - the coefficient of proportionality; $k_{f b}$ - transfer ratio of the feedback sensor for the output coordinate; $W_{\text {ext } 1}(p)=\left(1-e^{-T_{01} p}\right) / p-$ transfer function of the zero order holder in the main control channel; $W_{\text {ext } 2}(p)=\left(1-e^{-T_{02} p}\right) / p-$ transfer function of the zero order holder in the channel with the reference model.

In the combined control with the compensating discrete time equalizer a reference signal $y^{\prime}$ appears with the following image

$$
Y^{\prime}(z)=W_{e q 2}(z) E_{1}(z),
$$

which would be on the output of control object with perfect compensation of its dynamic properties both in static and dynamic modes. An error between the signal $y^{\prime}$ and real output signal $y$ of the controlled object defined as follows

$$
e_{2}=y^{\prime}-y \text {. }
$$

The control signal $u_{1}$ is formed in the main channel; it comes from the block for modification of the inverse transformation and enters the corresponding summator. Also, the input signal $u_{2}=k_{a v} e_{2}$ of this summator is formed by means of the compensating discrete time equalizer. Then, on the basis of the formula (1), signal $u$, that enters on the input of the controlled object is

$$
u=u_{1}+u_{2}=u_{1}+k_{a v}\left(y^{\prime}-y\right) .
$$

When the error $e_{2}=0$, the control is carried out using the main discrete time equalizer in the same way as in $[1,3]$. In

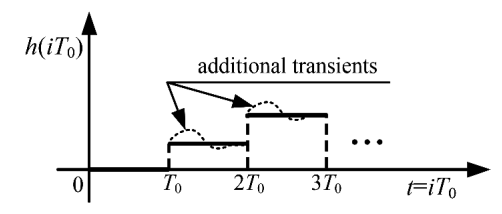

Fig. 2. Additional transients

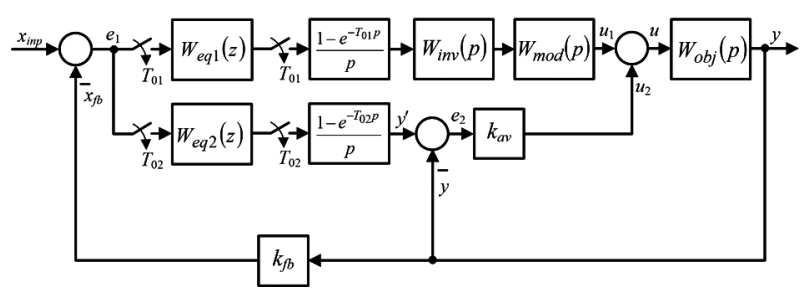

Fig. 3. Structural scheme of the combined of automatic control system on the basis of two discrete time equalizer 
dynamic operating modes, when $e_{2} \neq 0$, there is a combination control, at which on the input of the controlled object, in addition to the signal $u_{1}$, signal $u_{2}$ comes. This signal is formed by the compensating discrete time equalizer, which in this case works as a reference model of the object.

Let us determine how the coefficient $k_{a v}$ affects the overall transmission ratio of the system. It is reasonable to assume that the controlled object has a transmission coefficient $k_{o b j}$ and the inverse model of the controlled object $-1 / k_{o b j}$. Then, based on Fig. 4, through the implementation of structural transformations, the following relations for the general transfer coefficient of the system can be obtained

$$
k_{1}=\frac{1}{k_{a v} k_{o b j} k_{f b}+k_{a v} k_{o b j}+1} ; \quad k_{2}=1+k_{a v} k_{o b j} ; \quad k=\frac{1}{1+k_{f b}} .
$$

Thus, the total transmission ratio of the system does not change with the implementation of the combined control $k=$ $=1 /\left(1+k_{f b}\right)$. The value $k_{a v}$ in a real system can be selected by experimentation, starting from null with a certain step. The additional transient processes with oscillating nature may occur in dynamic modes for large values of $k_{a v}$ (for example, when the load is on or off).

The synthesis of the compensating discrete time equalizer is performed on the basis of the full compensation of the object dynamics by inverse model [6]. The discrete time equalizer must perform the system setup on a discrete transition function of finite duration, which is theoretically possible provided that the characteristic equation is reduced to the form $z^{n}$. Then the desired transfer function of the analogue system, which is digitized to a discrete, will be as follows (the numerator order may be less or equal to the order of the denominator)

$$
W_{\text {des }}(z)=\frac{a_{k} z^{k}+a_{k-1} z^{k-1}+\ldots+a_{1} z+a_{0}}{z^{k}},
$$

where $k$ is the order of the characteristic equation (must match or be greater than the order of the characteristic equation of the controlled object); $a_{k}, a_{k-1}, a_{k-2}, \ldots, a_{1}, a_{0}$ are the factors that characterize the transition function on increasing levels at each step of the quantization.

The number of levels of the transition function is determined by order of the characteristic equation of the desired transfer function using the formulas (4) [3]

$$
\left.\begin{array}{c}
c_{i}=\sum_{j=k-i}^{k} a_{j}, \quad \text { when } i \leq k \\
c_{i}=\sum_{i=0}^{k} a_{i}, \quad \text { when } i>k
\end{array}\right\} .
$$
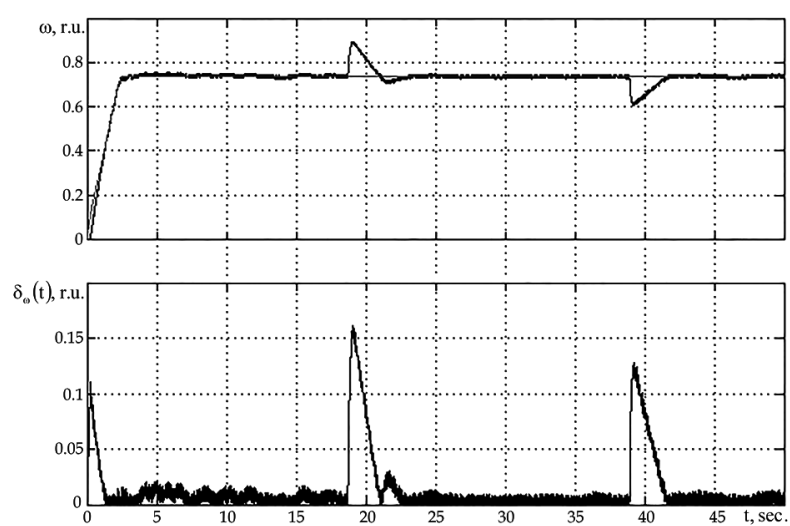

Fig. 4. Transition function for the speed in relative units and corresponding absolute value of the dynamic error (only one discrete time equalizer)
The values of the transitive function at the levels will be as follows

$$
\begin{gathered}
c_{0}=a_{k} ; \quad c_{1}=a_{k}+a_{k-1} ; \\
c_{2}=a_{k}+a_{k-1}+a_{k-2} ; \quad \ldots ; \quad c_{k-1}=\sum_{i=1}^{k} a_{i} ; \quad c_{k}=\sum_{i=0}^{k} a_{i} .
\end{gathered}
$$

Thus, each level of this function is the sum of the coefficients $a_{i}$, starting with the coefficient $a_{k}$ at the highest degree of $z$ in the numerator of the desired polynomial and ending with the coefficient $a_{0}$. The steady-state value is the sum of all numerator coefficients $\sum_{i=0}^{k} a_{i}$. The mathematical expression for the discrete time equalizer is the following

$$
\begin{gathered}
W_{e q}(z)=\frac{a_{k} z^{k}+a_{k-1} z^{k-1}+\rightarrow}{\left(1-k_{f b} a_{k}\right) z^{k}-k_{f b} a_{k-1} z^{k-1}-\rightarrow} \\
\rightarrow+a_{k-2} z^{k-2}+\ldots+a_{1} z+a_{0} \\
\rightarrow-k_{f b} a_{k-2} z^{k-2}-\ldots-k_{f b} a_{1} z-k_{f b} a_{0}
\end{gathered}
$$

The main discrete time equalizer is synthesized according to the formulas given in [3], depending on the order of the aperiodic neutrality of the control object.

For experimental research on automated electromechanical systems with discrete time equalizers, a laboratory-test bench was created, consisting of the following elements: the direct current (DC) drive motor KPA-561-U2; the generator DPM 290/3.8/30; the consumers of electric energy for creating a load; ammeter; transformer; rectifier; smoothing filter; rheostat; power converter with signal microcontroller; feedback sensor; external module for performing analog-digital conversion; a laptop with the necessary software.

Because of the complexity of the speed controlling algorithm of the DC motor on the basis of the discrete time equalizer, the test bench uses the board F28335 with the microcontroller TMS320F28335 [7] manufactured by Texas Instruments. The project environment for programming microcontroller TMS320F28335 is Code Composer Studio [8], which implements the main and the compensating discrete time equalizers.

The software code for the laboratory test bench system is written in the high-level $\mathrm{C}^{++}$programming language using object-oriented approaches, so it is hardware independent of the microprocessor type and can easily be transferred to another hardware base [9].

At the laboratory test bench, three series of nine experiments were carried out. In all experiments, quantized desired transition functions were worked out with a slight dynamic error, which occurred during start-up under the load, with a reset of the load and reloading.

As a result, it was found that the dynamic error in the process of the motor starting under the load action, which illustrates the maximum deviation of the experimentally received transition function from the desired transition function, reaches values from 5 to $14.5 \%$ when using only the main control channel with one discrete time equalizer. The application of the combined control with two discrete time equalizers allowed reducing the dynamic error to values from 1.8 to $8.1 \%$.

As an example, in Fig. 5 the results of one of the experiments are shown. Dependencies of an absolute value of the dynamic error and the speed (in relative units) were obtained in the combined control system with two discrete time equalizers (main and compensating). In Fig. 4 the similar dependencies were taken when the compensating discrete time equalizer was turned off. All other settings for program controllers, global output variables (speed tasks, quantization periods of equalizers, etc.) in both experiments are completely identical. 


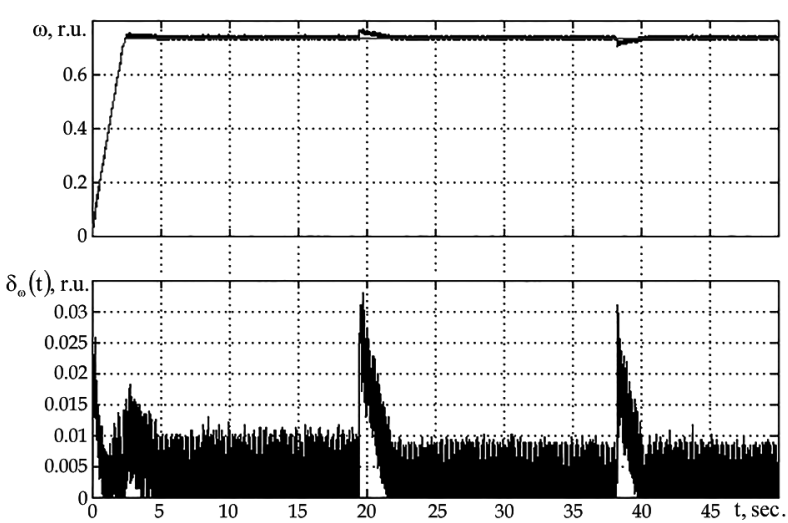

Fig. 5. Transition function for the speed in relative units and corresponding absolute value of the dynamic error (combined control)

Thus, due to the small ratio of transmission and soft static characteristics of the control object, the system required an impact on the proportional component to increase the dynamic accuracy and reduce the sensitivity to parametric and coordinate perturbations.

On average, as a result of the experiments, the use of combined control with two discrete time equalizers allowed reducing the dynamic errors both during start-up under the load and reset of the load from 3 to 6 times.

Conclusions:

1. The structure of the combined control system with two discrete time equivalents (main and compensating) allows increasing the dynamic accuracy and decreasing the sensitivity of the automatic control systems to coordinate perturbations.

2. The effectiveness of the developed method for designing the structure of the combined control system has been confirmed as a result of the series of experiments at the laboratory test bench.

3. Since the entire program code for the combined control system with two discrete time equalizers is written in a highlevel programming language $\mathrm{C} / \mathrm{C}^{++}$using object-oriented approaches, it is hardware-independent of the type of microprocessor and can easily be migrated from the hardware base of Texas Instruments to any other, such as DSP processors manufactured by Freescale or Analog Devices [10]. Due to this, the proposed software solutions are of considerable practical value and can be used in industry.

\section{References.}

1. Sheremet, O. I., Sadovoi, O. V., \& Sokhina, Yu. V. (2014). Concept of discrete time equalizer. Zbirnyk Naukovykh Prats Donbaskoho Derzhavnoho Tekhnichnoho Universytetu, 1(42), 147-151.

2. Kovalenko, S., Zicmane, I., \& Sauhats, A. (2015). Isolines of characteristic polynomial for power system static stability analysis. IEEE Eindhoven PowerTech, Eindhoven, 1-4. https:// doi.org/10.1109/PTC.2015.7232384.

3. Sheremet, O., \& Sadovoy, O. (2017). The method of automatic control systems synthesis on the base of discrete time equalizer. Naukovyi Visnyk Natsionalnoho Hirnychoho Universytetu, (4), 99-104.

4. Boashash, B. (2015). Time-Frequency Signal Analysis and Processing ( $2^{\text {nd }}$ ed.). Academic Press, Amsterdam, Netherlands.

5. Galias, Z., \& Yu, X. (2014). On zero-order holder discretization of delayed sliding mode control systems. Proc. IEEE Int. Symp. Circuits and Systems, Melbourne, Australia, 12551258. https://doi.org/10.1109 / ISCAS.2014.6865370.

6. Awatef, A., \& Mouna, B. H. (2017). Dynamic modeling and inverse dynamic control of mobile robot. In International Con- ference on Green Energy Conversion Systems (GECS), Hammamet, (pp. 1-5). https://doi.org/10.1109/GECS.2017.8066236. 7. Texas Instruments TMS320F28335 Tutorial. Introduction to TMS320F28335. Retrieved from http://archive.cnx.org/ contents/28f325b1-a7b5-4024-be16-95f0fc06c47e@2/introduction-to-tms $320 \mathrm{f} 28335$.

8. Welch, T. B., Wright, C.H.G., \& Morrow, M. G. (2017). Real-Time Digital Signal Processing from MATLAB to C with the $T M S 320 C 6 x D S P S$ ( $3^{\text {rd }}$ ed.). CRC Press, Boca Raton, USA. 9. Josipovic, L., George, N., \& Ienne, P. (2016). Enriching C-based High-Level Synthesis with parallel pattern templates. In International Conference on Field-Programmable Technology (FPT), Xi'an, (pp. 177-180). https://doi.org/10.1109/ FPT.2016.7929527.

10. Savadi, A., \& Yanamshetti, R. (2016). A survey on design of digital signal processor. In International Conference on Wireless Communications, Signal Processing and Networking (WiSPNET), Chennai, (pp. 2483-2486). https://doi. org/10.1109/WiSPNET.2016.7566590.

\section{Комбінована система керування на базі двох дискретних часових еквалайзерів}

\section{О. І. Шеремет ${ }^{1}$, О. В. Садовой², Ю. В. Сохіна ${ }^{2}$}

1 - Донбаська державна машинобудівна академія, м. Краматорськ, Україна, e-mail: sheremet-oleksii@ukr.net 2 - Дніпровський державний технічний університет, м. Кам’янське, Україна, e-mail: sadovoyav@ukr.net

Мета. Розробка методу побудови структури комбінованого керування з компенсацією параметричних і координатних збурень на основі двох дискретних часових еквалайзерів і виконання експериментальної оцінки ефективності застосування додаткового компенсуючого еквалайзера.

Методика. Теорія перехідних функцій кінцевої тривалості використовується для встановлення бажаних динамічних властивостей систем автоматичного керування на дискретних часових інтервалах. Принцип симетрії модифікованих структурних схем забезпечує формування бажаних динамічних властивостей замкненої системи 3 обмеженим коефіцієнтом підсилення.

Результати. Розроблено та експериментально перевірено метод побудови комбінованої структури керування 3 компенсацією параметричних і координатних збурень на основі двох дискретних часових еквалайзерів. Метод $є$ однією зі складових методології синтезу систем автоматичного керування, та передбачає завдання бажаних динамічних властивостей за вихідною координатою у графічному вигляді або у вигляді набору точок бажаної перехідної функції.

Наукова новизна. Уперше розроблено метод побудови структури комбінованої системи керування на основі двох дискретних часових еквалайзерів (основного й компенсаційного). Метод відрізняється від відомого (лише з одним дискретним часовим еквалайзером) уведенням паралельної коректувальної гілки з дискретним часовим еквалайзером, налаштованим на повну компенсацію динамічних властивостей об'єкта керування. Це дає можливість знизити чутливість системи до координатних і параметричних збурень.

Практична значимість. Результати досліджень можуть бути використані для побудови алгоритмів керування технічними об'єктами з їх подальшим програмним упровадженням у мікроконтролерну або мікропроцесорну систему керування.

Ключові слова: дискретний часовий еквалайзер, синтез, квантована перехідна функція, перехідна функція кіниевої тривалості, модифікований принци симетрії 


\section{Комбинированная система управления на базе двух дискретных временных эквалайзеров}

\section{А. И. Шеремет ${ }^{1}$, А. В. Садовой ${ }^{2}$, Ю. В. Сохина}

1 - Донбасская государственная машиностроительная академия, г. Краматорск, Украина, e-mail: sheremetoleksii@ukr.net

2 - Днепровский государственный технический университет, г. Каменское, Украина, e-mail: sadovoyav@ukr.net

Цель. Разработка метода построения структуры комбинированного управления с компенсацией параметрических и координатных возмущений на основе двух дискретных временных эквалайзеров и выполнение экспериментальной оценки эффективности применения дополнительного компенсирующего эквалайзера.

Методика. Теория переходных функций конечной длительности используется для установления желаемых динамических свойств систем автоматического управления на дискретных временных интервалах. Принцип симметрии модифицированных структурных схем обеспечивает формирование желаемых динамических свойств замкнутой системы с ограниченным коэффициентом усиления.

Результаты. Разработан и экспериментально проверен метод построения комбинированной структуры управления с компенсацией параметрических и коорди- натных возмущений на основе двух дискретных временных эквалайзеров. Метод является одной из составляющих методологии синтеза систем автоматического управления, и предусматривает задание желаемых динамических свойств по выходной координате в графическом виде или в виде набора точек желаемой переходной функции.

Научная новизна. Впервые разработан метод построения структуры комбинированной системы управления на основе двух дискретных временных эквалайзеров (основного и компенсационного). Метод отличается от известного (только с одним дискретным временным эквалайзером) введением параллельной корректирующей ветви с дискретным временным эквалайзером, настроенным на полную компенсацию динамических свойств объекта управления. Это позволяет снизить чувствительность системы к координатным и параметрическим возмущениям.

Практическая значимость. Результаты исследований могут быть использованы для построения алгоритмов управления техническими объектами с их последующим программным внедрением в микроконтроллерную или микропроцессорную систему управления.

Ключевые слова: дискретный временной эквалайзер, синтез, квантованная переходная функция, переходная функция конечной длительности, модифицированный приниип симметрии.

Recommended for publication by A.S. Kutsyk, Doctor of Technical Sciences. The manuscript was submitted 14.03.19. 